\title{
Pencapaian Zakat Terhadap Sustainability Development Goals (SDGs) Di Tiga Desa Di Kabupaten Majalengka: Implementasi Indeks BI-WAS
}

\author{
Gustani*, Marina Yulinar $^{2}$ \\ ${ }^{1}$ STEI Al - Ishlah Cirebon, gustani@ steialishlah.ac.id \\ ${ }^{2}$ STEI Al - Ishlah Cirebon, marinayulinar36@gmail.com
}

\begin{abstract}
Zakat as worship with a social dimension has the same goals as the Sustainable Development Goals (SDGs) program. This study aims to measure the state of clean water sources along with the current state of sanitation conditions in three villages in Majalengka Regency. The results of this study are expected to be a reference for zakat distribution programs. The method used is a mixed method approach, which is a combination of qualitative and quantitative. The measurement indicators use the Index for Sustainable Clean and Safe Water and Santation, or the BAZNAS Index for the Sustainability of Clean Water and Sanitation (BI-WAS) developed by the BAZNAS Puskas. The results of this study show that the BI-WAS value in the three villages is above 60\%, which means that public awareness of clean water and sanitation is good so that the existence of zakat programs related to this is less needed.
\end{abstract}

Keywords: Zakat; SDGs; BI-WAS

ABSTRAK

Zakat sebagai ibadah yang berdimensi sosial memiliki tujuan yang sama dengan program Sustainable Development Goals (SDGs). Penelitian ini bertujuan untuk mengukur keadaan sumber air bersih beserta keadaan terkini kondisi sanitasi di tiga Desa Kabupaten Majalengka. Hasil penelitian ini diharapkan dapat menjadi acuan program penyaluran zakat. Metode yang digunakan berupa pendekatan mixed method yaitu gabungan antara kualitatif dan kuantitatif. Indikator pengukuran menggunakan Index for Sustainable Clean and Safe Water and Santation,atau Indeks BAZNAS untuk Keberlanjutan Air Bersih dan Sanitasi (BIWAS) yang dikembangkan oleh Puskas BAZNAS. Hasil penelitian ini menunjukan nilai BIWAS di tiga desa diatas $60 \%$ yang berarti kesadaran masyarakat terhadap air bersih dan sanitasi sudah baik sehingga keberadaan program zakat yang berkaitan dengan tersebut kurang dibutuhkan.

Kata kunci: Zakat; SDGs; BI-WAS. 


\section{PENDAHULUAN}

Zakat memiliki peran, fungsi dan posisi penting dalam ajaran Islam. Ia merupakan salah satu sendi di antara sendi-sendi Islam lainnya. Zakat adalah ibadah fardiyah yang mengukuhkan hubungan vertikal antara seorang muzakki (pembayar zakat) dengan Tuhannya. Ia merefleksikan nilai spiritualitas yang mampu menumbuhkan nilai charity (kedermawanan) terhadap sesama manusia bahkan memiliki implikasi luas dalam aspek kehidupan sosial

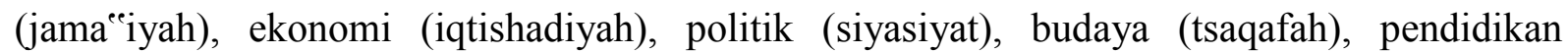
(tarbiyah) dan aspek-aspek lainnya. Selain, kekuatan menumbuhkan sikap peduli terhadap kekurangan dan penderitaan orang lain, zakat juga menjadi alat distribusi pendapatan (income distribution) secara adil dan merata terhadap asnaf (kelompok) sasaran zakat .

Pada perkembangannya, terutama di Indonesia para pihak saling melihat potensi sumber daya termasuk pendanaan untuk pencapaian Sustainable Development Goals (SDGs) dari banyak sektor tak terkecuali zakat. Dilihat dari jenis program yang dilakukan oleh kerja-kerja zakat, tidak terelakkan memiliki irisan yang jelas terhadap tujuan capaian SDGs. Misalnya pengentasan kemiskinan dan kelaparan, pendidikan berkualitas, air dan sanitasi, dll. Oleh karena itu, zakat dapat dikatakan sebagai salah satu instrument yang memiliki peran dan kontribusi yang strategis bagi capaian SDGs .

Daya tarik untuk mengaitkan pembangunan apa pun dengan Tujuan Pembangunan Berkelanjutan (SDGs) sedang meningkat. Zakat tidak terkecuali. Faktanya, semangat untuk mengasosiasikan zakat dengan SDGs menunjukkan kesimpulan bahwa pembangunan zakat akhirnya menemukan pasangan yang sempurna - yaitu SDGs (Shereeza Mohamed Saniff, 2020) Zakat memiliki potensi untuk mencapai Sustainable Development Goals (SDGs) yang diharapkan dapat tercapai pada tahun 2030 mendatang. Hal tersebut dapat dilihat dari beberapa model penyaluran zakat serta pemberdayaan mustahik yang telah dilakukan oleh BAZ dan LAZ

Zakat sebagai instrumen distribusi ekonomi bertujuan mengentaskan kemiskinan dan memajukan ekonomi. Sementara itu, SDGs adalah satu kesepakatan masyarakat dunia untuk mewujudkan dunia yang terbebas dari kemiskinan, berkehidupan yang bermartabat, adil, dan sejahtera, serta saling bekerja sama di antara mereka. Seuat masyarakat ideal yang diidamkan melalui perwujudan 17 tujuan pembangunan berkelanjutan (SDGs) di tahun 2030. Relasi dimaksud bersifat dua arah; zakat sebagai instrumen yang mendukung SDgs dan penerapan 
paradigma SDGs dalam pengelolaan zakat .

Zakat di Indonesia memiliki peran penting dalam mendukung pencapaian SDGs. Mengingat bahwa Zakat di Indonesia memiliki potensi yang sangat besar dan penyerapan potensinya belum optimal. Artinya peluang dan potensi masa depan masih terbuka lebar ditambah dukungan dari hukum zakat dan mendukung fatwa MUI .

Strategi Penguatan Pendistribusian dan Pendayagunaan Zakat yakni dengan irisan program SDGs dan zakat bertemu dalam sebuah tujuan untuk mengurangi kemiskinan termasuk kelaparan yang terjadi di dunia ini dan aneka turunannya. Beberapa pendapat dan pandangan muncul mencoba mengaitkan satu per satu dari poin-poin SDGs dengan interpretasi atas kerja zakat khususnya dari sudut penerima manfaat dan peruntukkan zakat. Kontribusi Zakat terhadap SDGs saat ini berfokus pada 5 tujuan yaitu Goal 1, Menghapus Kemiskinan, Goal 2, Mengakhiri kelaparan, Goal 3, Kesehatan yang baik dan kesejahteraan, Goal 4, Pendidikan Bermutu, dan Goal 5, Air bersih dan sanitasi. Ada juga pendapat yang menyebutkan bahwa di setiap tujuan SDGs merupakan poin-poin yang seluruhnya sesuai dengan zakat, atau tepatnya dapat didukung oleh kerja zakat..

Hasil riset terdahulu menunjukan terdapat tiga program skala prioritas BAZNAS RI yang memiliki kaitan erat dalam mewujudkan 17 SDGs yaitu Bina Lingkungan (W= 0,47783), Kemitraan untuk Semua Tujuan Pembangunan (W= 0,00486) dan Zakat Bina Lingkungan (W=0,07367) . Penyaluran zakat baru-baru ini oleh Badan Zakat Nasional Republik Indonesia (BAZNAS), seperti pembangunan WC pribadi untuk rumah tangga kurang mampu, telah berkontribusi pada gagasan bahwa zakat mempromosikan keberlanjutan air bersih dan sanitasi (SDG 6). Hasil riset menjelaskan perspektif masyarakat setempat setelah menerima bantuan, termasuk identifikasi pengurangan jumlah penduduk lokal yang terkena diare. Informasi ini dapat memvalidasi hubungan antara kesehatan, air dan sanitasi .

Puskas BAZNAS (2019) telah menerbitkan kajian konseptual mengembangkan suatu indikator yang dapat mengukur keadaan sumber air bersih di suatu wilayah pedesaan, beserta keadaan terkini kondisi sanitasi penduduk desa tersebut. Alat ukur yang dikembangkan bernama BAZNAS Index for Sustainable Clean and Safe Water and Santation, atau Indeks BAZNAS untuk Keberlanjutan Air Bersih dan Sanitasi (BI-WAS). Hasil implementasi BIWAS tahun 2019 di empat desa menunjukan hasil yang berbeda-beda. Desa Ranggung dan Desa Kendel mendapatkan nilai BIWAS dalam range 61 - 80, dengan nilai BI-WAS masing- 
masing 76 dan 70 persen. Desa Pesanggrahan berada di range 41 - 60 dengan nilai BI-WAS 41 persen. Terakhir, Balai Baiak III Koto berada di range 21 - 40, dengan nilai BI-WAS 23 persen .

Penelitian ini mencoba untuk melakukan pengukuran BI-WAS di desa yang berbeda yaitu tiga desa di wilayah Kabupaten Majalengka, yaitu desa Ligung, desa Majasari, dan desa Jatitujuh untuk mengukur keadaan sumber air bersih di suatu wilayah pedesaan, beserta keadaan terkini kondisi sanitasi penduduk desa tersebut. Hasil pengukuran ini dapat dijadikan bahan pertimbangan lembaga zakat dalam program penyaluran

\section{METODE}

\section{Desain penelitian}

Metode yang digunakan berupa pendekatan mixed method yaitu gabungan antara kualitatif dan kuantitatif. Pendekatan mixed method dilakukan dengan metode Sequential Exploratory Design. Metode sequential exploratory design adalah metode yang dilakukan secara berurutan dimulai dari metode kualitatif dan selanjutnya kuantitatif. Output dari metode kualitatif akan menjadi sumber bahan untuk proses lanjutan pada metode kuantitatif .

Penelitian ini terlebih dahulu telah menggunakan pendekatan kualitatif, yaitu berupa survey untuk melakukan analisis tahap awal untuk mendapatkan 3 nilai skala linkert yang ada didalam BI-WAS dari desa yang menjadi objek kajian. Selanjutnya, kajian ini menggunakan pendekatan kuantitatif dengan menghitung hasil survei skala linkert BI-WAS dengan mengkalikan dan menjumlahkan dengan bobot-bobot yang ada di dalam dimensi dan variabel BI-WAS dengan pendekatan matematis simple additive weighting (SAW).

Tahap terakhir adalah validasi kualitatif dengan interview lebih dalam dengan penduduk di tiga desa yang menjadi objek penelitian. Pemilihan tiga desa dan pemilihan penduduk setempat sebagai informan dalam validasi kualitatif dilakukan dengan metode purposive sampling, dimana Peneliti dapat dengan sukarela memilih ke-tiga desa tersebut dan orangorang setempat, dengan landasan yang logis.

Sampel dalam penelitian ini adalah tiga desa yang berada di kecamatan ligung dan kecamatan jatitujuh Kabupaten Majalengka yaitu Desa Ligung, Desa Majasari dan Desa Jatitujuh. 


\section{LITERATUR REVIEW}

\section{Indikator BI-WAS}

BAZNAS Index for Sustainable Clean and Safe Water and Santation, atau Indeks BAZNAS untuk Keberlanjutan Air Bersih dan Sanitasi (BI-WAS) terdiri dari 4 dimensi dan 15 variabel dengan masing-masing bobot yang berbeda-beda.

Tabel 1 : Indikator BI-WAS

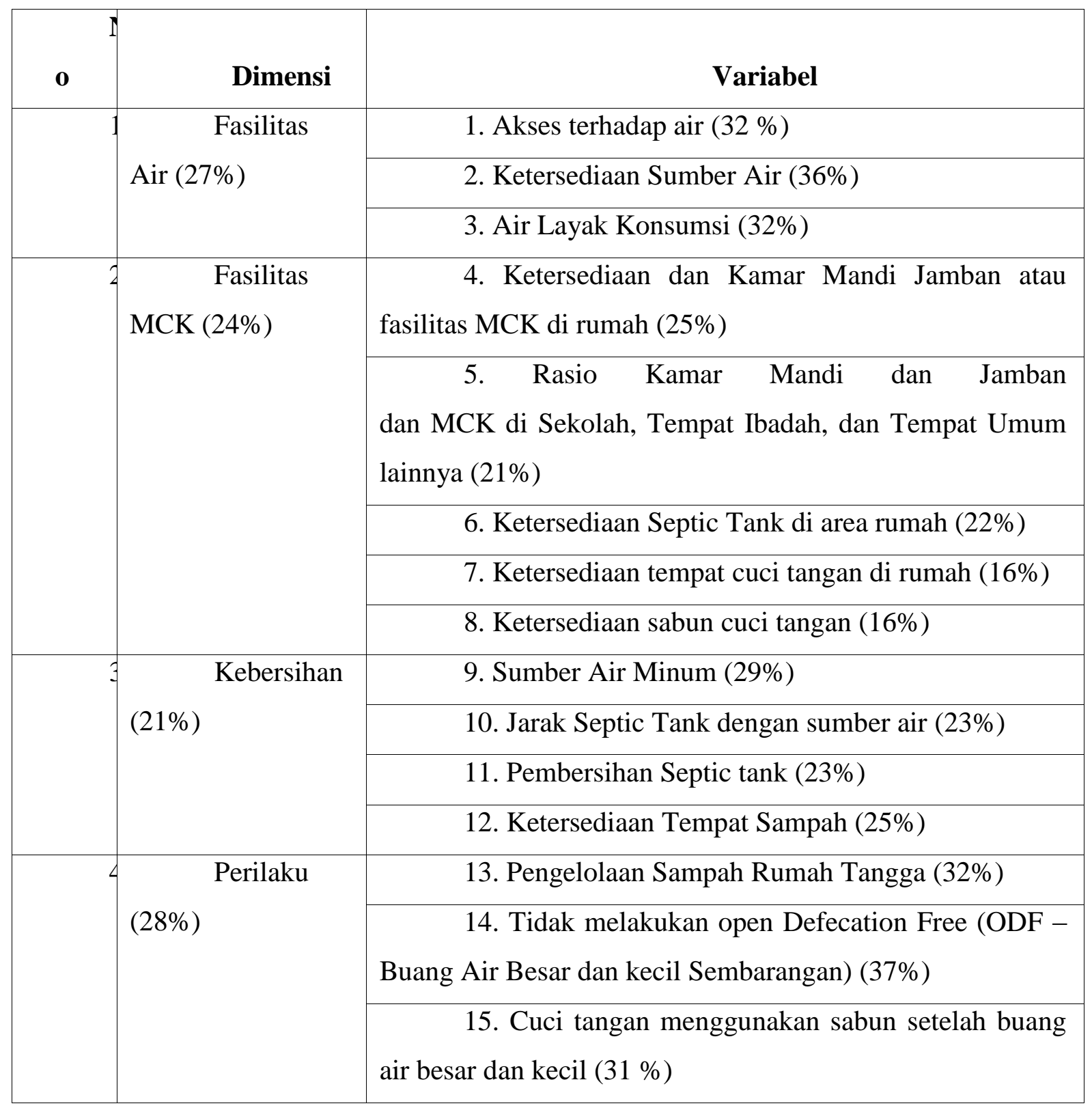




\section{Model Perhitungan}

Untuk menghitung indikator kualitatif diatas sebagaimana pada tabel 1 , bobot yang telah diberikan kepada masing-masing dimensi dan variable berfungsi menjadi nilai koefisien setiap dimensi dan variable kualitatif tersebut. Untuk metode perhitungan menggunakan pendekatan simple additive weighting (SAW) atau pembobotan aditif sederhana yang dikembangkan oleh Puskas BAZNAS. Formula perhitungan yang digunakan dalam penelitian ini adalah sebagai berikut:

\section{Formula 1. Indeks fasilitas air (IFA01)}

$$
\begin{aligned}
& x x S+x x S+x x S \text { atau } \\
& (x S+x S+x S)
\end{aligned}
$$

Dimana:

(01) adalah dimensi fasilitas air (lihat tabel 3.2)

adalah bobot 0.27 yang dibubuhkan ke dimensi 01 (lihat tabel 3.3)

adalah bobot 0.32 yang dibubuhkan ke variabel 1 dimensi 01 (lihat tabel 3.3), adalah bobot 0.36 yang dibubuhkan ke variabel 2 dimensi 01 (lihat tabel 3.3), adalah bobot 0.32 yang dibubuhkan ke variabel 3 dimensi 01 (lihat tabel 3.3), $S$ adalah nilai skala linkert diantara diantara 1-5 sesuai temuin dari survey (lihat tabel 3.2)

Lebih lanjut IFA01

Dimana:

IFA1 $=x \quad x S$

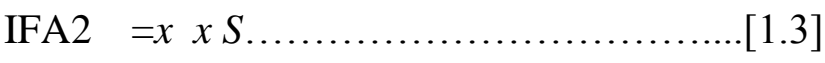

IFA3 $=x \quad x S$.

\section{Formula 2. Indeks fasilitas MCK (IFMCK02)}

$(02)=x \times S+x \times S+x \times S+x \times S+x \times S$ atau,

$(02)=(x S+x S+x S+x S+x)$

Dimana:

(02) adalah dimensi fasilitas MCK (lihat tabel 3.2)

adalah bobot 0.24 yang dibubuhkan ke dimensi 02 (lihat tabel 3.3), 
adalah bobot 0.25 yang dibubuhkan ke variabel 4 dimensi 02 (lihat tabel 3.3), adalah bobot 0.21 yang dibubuhkan ke variabel 5 dimensi 02 (lihat tabel 3.3), adalah bobot 0.22 yang dibubuhkan ke variabel 6 dimensi 02 (lihat tabel 3.3), adalah bobot 0.16 yang dibubuhkan ke variabel 7 dimensi 02 (lihat tabel 3.3), adalah bobot 0.16 yang dibubuhkan ke variabel 7 dimensi 02 (lihat tabel 3.3)

$S$ adalah nilai skala linkert diantara 1-5 sesuai temuan dari survey (lihat tabel 3.2). Lebih lanjut IFMCK02 =

[2.1]

Dimana:

IFMCK4 $=x \times S$

IFMCK5 $=x \times S$

IFMCK6 $=x \times S$

IFMCK7 $=x \quad x S$

IFMCK8 $=x \times S$

\section{Formula 3. Indeks Kebersihan (IK03)}

$(03)=x \times S+x \times S+x \times S+x \times S$ atau,

$(03)=x(x S+x S+x S+x S)$

Dimana:

(03) adalah dimensi kesehatan (lihat tabel 3.2)

adalah bobot 0.21 yang dibubuhkan ke dimensi 03 (lihat tabel 3.3),

adalah bobot 0.29 yang dibubuhkan ke variabel 9 dimensi 03 (lihat tabel 3.3), adalah bobot 0.23 yang dibubuhkan ke variabel 10 dimensi 03 (lihat tabel 3.3), adalah bobot 0.23 yang dibubuhkan ke variabel 11 dimensi 03 (lihat tabel 3.3), adalah bobot 0.25 yang dibubuhkan ke variabel 12 dimensi 03 (lihat tabel 3.3), $S$ adalah nilai skala linkert diantara 1-5 sesuai temuan dari survey (lihat tabel 3.2).

Lebih lanjut IK03 = [3.1]

Dimana:

IK9

$$
=x \times S
$$

$\mathrm{IK} 10=x \times S$

$\mathrm{IK} 11=x \times S$ 
$\mathrm{IK} 12=x \times S$

\section{Formula 4. Indeks Perilaku (IP04)}

$(04)=x \times S+x \times S+x \times S$ atau,

$(04)=(x S+x S+x S)$

Dimana:

(04) adalah dimensi perilaku (lihat tabel 3.2)

adalah bobot 0.28 yang dibubuhkan ke dimensi 04 (lihat tabel 3.3),

adalahbobot 0.32 yang dibubuhkan ke variabel 13 dimensi 04 (lihat tabel 3.3),

adalah bobot 0.37 yang dibubuhkan ke variabel 14 dimensi 04 (lihat tabel 3.3),

adalah bobot 0.31 yang dibubuhkan ke variabel 15 dimensi 04 (lihat tabel 3.3),

$S$ adalah nilai skala linkert diantara 1-5 sesuai temuan dari survey (lihat tabel 3.2).

Lebih lanjut IP04 [4.1]

Dimana:

IP13 $=x \quad x S$

IP14 $=x \times S$

$\mathrm{IP} 15=x \times S$

\section{Formula 5. BI-WAS}

$\mathrm{BI}-\mathrm{WAS}=\mathrm{IFA01}+\mathrm{IFMCK}+\mathrm{IK} 03+\mathrm{IP} 04$

Dengan formula SAW yang telah dikembangkan diatas, maka nilai angka tertinggi dalam BI-WAS adalah 100 persen jika simple (suatu desa/daerah) mendapatkan nilai 5 dari penilaian skala linkert. Sebaliknya, nilai terendah adalah 0 jika sample tidak mendapatkan nilai dari skala linkert.

Untuk menerjemahkan angka yang dihasilkan oleh prosedur BI-WAS diatas, maka terlebih dahulu penting untuk mencari nilai interval untuk menentukan nilai kelas dalam menginterprestasi temuan ketika menggunakan pengukuran BI-WAS. Berikut dibawah ini dilakukan perhitungan nilai interval.

Tabel 2 Acuan untuk Interprestasi Angka BI-WAS 


\begin{tabular}{|c|c|c|c|}
\hline $\begin{array}{r}\text { Rentan } \\
\text { g Nilai }(\%)\end{array}$ & $\begin{array}{l}\text { Definisi Rentang } \\
\text { Nilai }\end{array}$ & Interprestasi & Implikasi \\
\hline $0-20$ & $\begin{array}{l}\text { Keadaan daerah } \\
\text { yang dikaji sangat tidak } \\
\text { ideal dengan indikator BI- } \\
\text { WAS }\end{array}$ & $\begin{array}{l}\text { Kesadaran } \\
\text { masyarakat dan } \\
\text { kondisi sanitasi total } \\
\text { tidak baik }\end{array}$ & $\begin{array}{l}\text { Keberadaan } \\
\text { program BAZNAS } \\
\text { sangat dibutuhkan }\end{array}$ \\
\hline $21-40$ & $\begin{array}{ll} & \text { Keadaan daerah } \\
\text { yang dikaji tidak ideal } \\
\text { dengan indikator BI-WAS }\end{array}$ & $\begin{array}{l}\text { Keadaan } \\
\text { masyarakat dan } \\
\text { kondisi sanitasi total } \\
\text { kurang baik }\end{array}$ & $\begin{array}{l}\text { Keberadaan } \\
\text { program BAZNAS } \\
\text { dibutuhkan }\end{array}$ \\
\hline $41-60$ & $\begin{array}{l}\text { Keadaan daerah } \\
\text { yang dikaji cukup ideal } \\
\text { dengan indikator BI-WAS }\end{array}$ & $\begin{array}{l}\text { Kesadaran } \\
\text { masyarakat dan } \\
\text { kondisi sanitasi total } \\
\text { cukup baik }\end{array}$ & $\begin{array}{l}\text { Keberadaan } \\
\text { program BAZNAS } \\
\text { cukup dibutuhkan }\end{array}$ \\
\hline $61-80$ & $\begin{array}{l}\text { Keadaan daerah } \\
\text { yang dikaji ideal dengan } \\
\text { indikator BI-WAS }\end{array}$ & $\begin{array}{l}\text { Kesadaran } \\
\text { masyarakat dan } \\
\text { kondisi sanitasi total } \\
\text { baik }\end{array}$ & $\begin{array}{r}\text { Keberadaan } \\
\text { program BAZNAS } \\
\text { kurang dibutuhkan }\end{array}$ \\
\hline $\begin{array}{l}81- \\
100\end{array}$ & $\begin{array}{l}\text { Keadaan daerah } \\
\text { yang dikaji sangat ideal } \\
\text { dengan indikator BI-WAS }\end{array}$ & $\begin{array}{l}\text { Kesadaran } \\
\text { masyarakat dan } \\
\text { kondisi sanitasi total } \\
\text { sangat baik }\end{array}$ & $\begin{array}{l}\text { Keberadaan } \\
\text { program BAZNAS } \\
\text { tidak dibutuhkan }\end{array}$ \\
\hline
\end{tabular}

Sumber : Indeks BAZNAS untuk Keberlanjutan Air Bersih dan Sanitasi (BI-WAS), 2019, hal 49-50

\section{HASIL DAN PEMBAHASAN}

Bagian ini akan menjelaskan interpretasi untuk temuan-temuan dari pengukuran BIWAS yang telah dilakukan di tiga desa di Kabupaten Majalengka yang menjadi objek dalam penelitian ini. Berikut ini hasil perhitungan BI-WAS : 
Tabel 3: Hasil Kajian BI-WAS Tiga Desa di Kabupaten Majalengka

\begin{tabular}{|c|c|c|c|c|c|c|c|c|c|c|c|}
\hline \multirow{2}{*}{\multicolumn{2}{|c|}{ Dimensi }} & \multirow{3}{*}{$\begin{array}{l}\text { Boot } \\
0,27\end{array}$} & \multirow{2}{*}{\multicolumn{2}{|c|}{ Variable }} & \multirow{3}{*}{$\begin{array}{l}\text { Boot } \\
0,32\end{array}$} & \multirow{2}{*}{\multicolumn{2}{|c|}{$\begin{array}{c}\text { Jatitujuh } \\
\text { Hasil }\end{array}$}} & \multirow{2}{*}{\multicolumn{2}{|c|}{$\begin{array}{l}\text { Ligung } \\
\text { Hasil }\end{array}$}} & \multirow{2}{*}{\multicolumn{2}{|c|}{$\frac{\text { Majasari }}{\text { Hasil }}$}} \\
\hline & & & & & & & & & & & \\
\hline FAO1 & $D y$ & & $\mathbf{1}$ & $V_{1}^{\prime \prime}$ & & 4 & 0,345 & 3 & 0,259 & 5 & 0,432 \\
\hline & & 0,27 & 2 & $\nabla_{1}^{2}$ & 0,36 & 4 & 0,388 & 4 & 0,388 & 4 & 0,388 \\
\hline & & 0,27 & 3 & $v_{1}^{3}$ & 0,32 & 4 & 0,345 & 4 & 0,345 & 3 & 0,259 \\
\hline \multicolumn{6}{|c|}{ IFAO1 } & \multicolumn{2}{|c|}{0,215} & \multicolumn{2}{|c|}{0,198} & \multicolumn{2}{|c|}{0,215} \\
\hline \multirow[t]{5}{*}{ IFMCK 02 } & $D_{2}^{2}$ & 0,24 & 4 & $\mathbb{V}_{2}^{3}$ & 0,25 & 5 & 0,3 & 5 & 0,3 & 5 & 0,3 \\
\hline & & 0,24 & 5 & $\mathbb{2}^{5}$ & 0,21 & 4 & 0,201 & 5 & 0,252 & 5 & 0,252 \\
\hline & & 0,24 & 6 & $\mathbb{2}_{2}^{6}$ & 0,22 & 5 & 0,264 & 5 & 0,264 & 5 & 0,264 \\
\hline & & 0,24 & 7 & $\mathbb{2}_{2}^{3}$ & 0,16 & 4 & 0,153 & 5 & 0,192 & 4 & 0,153 \\
\hline & & 0,24 & $\mathbf{8}$ & $\mathbb{v e}_{2}^{3}$ & 0,16 & 5 & 0,192 & 5 & 0,192 & 5 & 0,192 \\
\hline \multicolumn{6}{|c|}{ IFMCKO2 } & \multicolumn{2}{|c|}{0,222} & \multicolumn{2}{|c|}{0,24} & \multicolumn{2}{|c|}{0,232} \\
\hline IKO3 & $B D_{3}^{a}$ & 0,21 & 9 & $\mathbb{v}_{3}^{3}$ & 0,29 & 4 & 0,243 & 4 & 0,243 & 4 & 0,243 \\
\hline & & 0,21 & 10 & $v_{3}^{1,10}$ & 0,23 & 3 & 0,144 & 2 & 0,096 & 2 & 0,096 \\
\hline & & 0,2 & 11 & $\sqrt{31}$ & 0,23 & 1 & 0,0 & $\mathbf{1}$ & 0,048 & 1 & 0,048 \\
\hline & & 0,21 & 12 & $\sqrt{3}$ & 0,25 & $\mathbf{1}$ & 0,052 & $\mathbf{1}$ & 0,52 & 2 & 0,105 \\
\hline \multicolumn{6}{|c|}{ IK03 } & \multicolumn{2}{|c|}{0,097} & \multicolumn{2}{|c|}{0,181} & \multicolumn{2}{|c|}{0,098} \\
\hline IPO4 & $D_{3}^{-4}$ & 0,28 & 13 & $v_{4}^{13}$ & 0,32 & 2 & 0,179 & 2 & 0,179 & 2 & 0,179 \\
\hline & & 0,28 & 14 & $v_{s}^{1 / 3}$ & 0,37 & 5 & 0,518 & 5 & 0,518 & 4 & 0,414 \\
\hline & & 0,28 & 15 & $V_{4}^{15}$ & 0,31 & 4 & 0,347 & 5 & 0,434 & 4 & 0,347 \\
\hline \multicolumn{6}{|c|}{ IPO4 } & \multicolumn{2}{|c|}{0,208} & \multicolumn{2}{|c|}{0,226} & \multicolumn{2}{|c|}{0,188} \\
\hline \multicolumn{6}{|c|}{ BI-WAS } & \multicolumn{2}{|c|}{$74 \%$} & \multicolumn{2}{|c|}{$84 \%$} & \multicolumn{2}{|c|}{$73 \%$} \\
\hline
\end{tabular}

\section{BI-WAS Desa Jatitujuh}

Untuk observasi langsung telah dilakukan di Desa Jatitujuh Kabupaten Majalengka, hal ini dilakukan selain untuk mendapatkan hasil yang otentik untuk penilaian skala linkert yang telah dirancang di pembahasan sebelumnya, hal tersebut juga kritikal untuk mengeksplorasi secara terperinci mengenai kondisi air dan sanitasi di Jatitujuh.

Desa Jatitujuh merupakan karawangnya Jawa Barat yang artinya areanya luas dalam hal pertanian, pertanian di Desa Jatitujuh mayoritas menggunakan air irigasi yang ada tersiernya lebih potensial dan Desa jatitujuh hanya kebagian air irigasi dari yang paling ujung, artinya kalau irigasi di ujung namun arealnya lebar otomatis airnya kurang. Sedangkan Jatitujuh mempunyai cimanuk, cipelang, dan bendungan rentang. Alangkah naifnya jatitujuh kekurangan air. Padahal banyak pasokan airnya namun bukan hak orang Jatitujuh walaupun bendungannya berada di Jatitujuh, karena bendungan rentang walaupun posisinya di Jatitujuh adalah hak nya cipelang yaitu hak Kabupaten Indramayu. Bendungan rentang dibagi menjadi 
tiga yang pertama ke kanan situ praja untuk Kabupaten Cirebon, kiri cipelang untuk Kabupaten indramayu dan terakhir Jatitujuh di Majalengka kebagian air yang terakhir ada bendungan rentang. Sedangkan untuk Air rumah tangga di Desa Jatitujuh ini aman karena sudah ada air dari PAM.

Dan untuk indikator Fasilitas Air (IFA04), Desa Jatitujuh mendapatkan nilai skala linkert 4 untuk ketiga variabel dalam indikator ini dan untuk indikator MCK (IFMCK02) mendapatkan skala linkert 5 untuk variabel 4, 6 dan 8 sedangkan untuk variabel 5 dan 7 mendapatkan skala linkert 4, Kebersihan (IK03) mendapatkan skala linkert 1 untuk pembersihan septic tank dan ketersediaan tempat sampah, dan untuk sumber air minum mendapatkan skala linkert 4, Jarak septic tank mendapatkan skala linkert 3, sedangkan Prilaku (IP04) untuk pengelolaan sampah mendapatkan skala linkert 2, dan untuk variabel 14 dan 15 mendapatkan skala linkert 5 dan 4. BI-WAS untuk Desa Jatitujuh adalah 74 persen. Untuk angka ini, maka dapat diinterpretasi keadaan Desa Jatitujuh Ideal dengan indikator BI-WAS yang menggambarkan kesadaran masyarakat dan kondisi sanitasi yang baik, diantara ke 4 Dimensi fasilitas MCK di Desa Jatitujuh sangat kecil yaitu dengan nilai 0,222 dibandingkan dengan ligung dan Majasari. Maka program BAZNAS terkait pembangunan sumber mata air bersih rumah tangga dan aman serta fasilitas sanitasi belum terlalu dibutuhkan. Tetapi untuk yang mempunyai sawah/para petani dibutuhkan program pembangunan sumber mata air, karena mayoritas para penduduk di Desa Jatitujuh mata pencaharian mereka itu bertani.

\section{BI-WAS Desa Ligung}

Observasi langsung telah dilakukan di Desa Ligung Kabupaten Majalengka, temuan untuk Desa ini adalah sebagaimana berikut Untuk ketiga variabel dalam indikator Fasilitas Air (IFA01), Desa ini mendapatkan nilai skala linkert 3 untuk akses terhadap air, 4 untuk ketersediaan sumber air, dan 4 untuk kebersihan air/air konsumsi layak. Sedangkan untuk variabel dalam indikator ini Fasilitas MCK (IFMCK02), desa ini mendapatkan 5 untuk masing-masing variabel ke 4 dan 6. Sedangkan untuk variabel 7 dan ke 8 dalam indikator IFMCK02 ini, desa ini mendapatkan nila skla linkert 5 dan 5.

Lebih lanjut, dalam indikator kebersihan (IK03), Desa ligung mendapatkan nilai skala linkert 1, dalam indikator prilaku (IP04), Desa ini mendapatkan nilai skala linkert 2 untuk masalah pengelolaan sampah dan linkert 5 untuk variabel 14 dan 15 . Untuk temuan-temuan 
ini, maka BI-WAS untuk Desa ini adalah 84 persen. Dengan demikian, interpretasi untuk angka ini adalah keadaan Desa ini Sangat Ideal dengan indikator BI-WAS yang menggambarkan kondisi sanitasi total tetapi untuk variabel ke 11 dan 12 masih belum optimal karena masih dalam angka skala linkert 1 dan untuk nilai yang paling kecil pada dimensinya yaitu Dimensi Kesehatan dengan nilai 0,181. Maka program BAZNAS terkait pembangunan sumber mata air bersih rumah tangga dan aman serta fasilitas sanitasi tidak terlalu dibutuhkan.

\section{BI-WAS Desa Majasari}

Negara Indonesia memiliki dua musim, yaitu musim hujan dan musim kemarau. Seringkali setiap tahunnya, Indonesia mengalami kondisi dimana musim kemarau lebih panjang dari biasanya. Hal ini mengakibatkan terjadinya kekeringan di beberapa daerah khususnya di beberapa bagian Desa Majasari, Kejadian ini terus berulang dan berulang, banyak pihak yang dirugikan oleh kondisi kemarau panjang yang mengakibatkan kekeringan. Salah satunya adalah petani yang tanamannya terancam gagal panen karena kekeringan, selain itu kekeringan juga menyebabkan air bersih menjadi langka.

Observasi langsung telah dilakukan di Desa Majasari Kabupaten Majalengka. Dalam penilaian indikator Fasilitas Air (IFA01), Desa ini mendapat nilai skala linkert 5 untuk variabel ketersediaan sumber air dan untuk variabel 3 (Air Layak Konsumsi) nilai skala linkertnya yaitu 3, untuk air layak konsumsi di desa ini sebagiannya air untuk minum asin walaupun air itu dari sumur ataupun PDAM. Untuk indikator fasilitas MCK (IFMCK02), Desa ini mendapatkan nilai skala linkert 5, dalam indikator Kebersihan (IK03) untuk variabel pembersihan septic tank dan ketersediaan tempat sampah nilai skala linkert 1, sedangkan untuk IP04 nilai skala linkert 4. Pada dimensi prilaku untuk majasari mendapat nilai paling rendah 0,188 .

Untuk temuan-temuan diatas, maka dalam perhitungan akhir BI-WAS Desa Majasari mendapatkan 73 persen. Untuk angka ini, maka diinterpretasikan bahwa keadaan Desa Majasari yang dikaji Ideal dengan indikator BI-WAS yang menggambarkan kesadaran masyarakat dan kondisi sanitasi total baik.

\section{Kontribusi Zakat Pada SDG's}

Zakat merupakan penyaluran kekayaan oleh muslim yang berkecukupan sesuai dengan 
ketentuan agama untuk diberikan kepada yang lebih membutukan. Adapun para penerima zakat yaitu fakir, miskin, amil, mualaf, budak orang yang berhutang, fisabilillah (yang berjuang dijalan Allah), dan ibnu sabil (yang sedang dalam perjalanan).

Tujuan dari zakat adalah untuk memberikan layanan, manfaat dan meningkatkan kesejahteraan bagi para penerimanya. Dapat dikatakan bahwa zakat menjadi instrument pembangunan yang penting bagi negara. Karena perannya yang sangat strategis dalam hal pembangunan berkelanjutan, Indonesia melakukan institusionalisasi terhadap pengelolaan zakat. UU No. 23 Tahun 2011 memberikan kepastian hukum institusionalisasi zakat oleh lembaga negara non-struktural, BAZNAS. Hal ini menunjukan bahwa negara ingin menjadikan zakat sebagai salah satu instrument yang memiliki peran dan kontribusi untuk pembangunan.

Kontribusi zakat terhadap SDG's saat ini berfokus pada 5 tujuan, yaitu menghapus kemiskinan, mengakhiri kelaparan, kesehatan yang baik dan kesejahteraan, pendidikan yang bermutu dan Air bersih dan sanitasi. Berdasarkan hasil observasi peneliti di tiga desa menunjukan bahwa baznas Kabupaten Majalengka untuk tiga desa ini hanya berkontribusi dalam kebutuhan pokoknya saja belum menyalurkan bantuan air bersih dan sanitasi adapun di Desa Majasari telah menerima bantuan air bersih dari BPBD (Badan Penanggulangan Bencana Daerah).

\section{KESIMPULAN}

Berdasarkan hasil penelitian ini, didapati nilai BI-WAS yang berbeda-beda di tiga desa di Kabupaten Majalengka. Desa Jatitujuh dan Desa Majasari berada di range 61 - 80 dengan nilai BI-WAS masing-masing 74\% dan $73 \%$ yang berarti kondisi desa Ideal dengan indikator BI-WAS yang menunjukan kesadaran masyarakat dan kondisi sanitasi total baik sehingga keberadaan program Lembaga zakat kurang dibutuhkan. Akan tetapi, berdasarkan observasi direkomendasikan program-program terkait pendampingan air bersih dan sanitasi harus tetap di adakan di dua desa ini. Sedangkan Desa Ligung nilai range berada pada 81-100 dengan nilai BI-WAS 84\% yang berarti keadaan daerah yang dikaji sangat ideal dengan indikator BIWAS yang menunjukan kesadaran masyarakat dan kondisi sanitasi total sangat baik sehingga keberadaan program BAZNAS tidak dibutuhkan. 


\section{REFERENSI}

Amymie, F. (2017). Optimalisasi Pendistribusian Dan Pendayagunaan Dana Zakat Dalam Pelaksanaan Tujuan Program Pembangunan Berkelanjutan (Sdgs). Anida (Aktualisasi Nuansa Ilmu Dakwah) Vol 17, No. 1, 1-18.

Hudaefi, F., Saoqi, A., Farchatunnisa, H., \& Junari, U. (2020). Zakat And Sdg 6: A Case Study Of Baznas, Indonesia. Journal Of Islamic Monetary Economics And Finance, 6(4), 919 - 934.

Hasanah, M. (2020). Zakat Digital: Pengumpulan Zakat Berbasis Teknologi Dalam Mewujudkan Sustainable Development Goals (Sdgs). Jurnal Ekonomi Dan Keuangan Islam, 1(1), 112-121, 112-121.

Hidayat, H. K. (2008). Panduan Pintar Zakat. Jakarta: Qultum Media.

Khalifah, M.H., Nurzaman, M.S.,\& Nafis, M.C. (2017). Optimization Of Baznas Programs On Sustainable Development Goals (Sdgs): Analytic Network Process Approach (Anp). International Journal Of Zakat, Vol. 2 (2), 71-83.

Maksum, M. (2018). Fikih Zakat On Sdgs. Tangerang Selatan: Mumtaza Press.

Puskas Baznas. (2017). Sebuah Kajian Zakat On Sdgs; Peran Zakat Dalam Sustainable Development Goals Untuk Pencapaian Maqashid Syariah. Jakarta Pusat: Puskas Baznas.

Puskas Baznas. (2019). Indeks Baznas Untuk Keberlanjutan Air Bersih Dan Sanitasi (Bi-Was) Kajian Konseptual. Jakarta: Puskas Baznas.

Puskas Baznas. (2019). Kajian Ilmiah Pengukuran Air Bersih Dan Sanitasi: Implementasi BiWas Di Empat Desa. Jakarta: Puskas Baznas.

Amalia, R.Y., \& Huda, N. (2020). Role Of Zakat In Achieving Sustainable Development Goals (Sdgs) In Indonesia. International Journal Of Zakat And Islamic Philanthropy Vol 2 Issue 2, 199-204.

Sugiyono. (2012). Metode Penelitian Kuantitatif Kualitatif Dan R\&B. Bandung: Alfabeta. 